\title{
Insights of Anthropology
}

\section{Acmeological Research Based on Personal History}

\section{NA Pakshina* and MV Pravdina}

\section{Arzamas Polytechnic Institute of RE Alekseev, Nizhny Novgorod State Technical University, Russia}

\begin{abstract}
The paper deals with one of the urgent and complex problems, namely the importance for personnel departments and recruiting agencies to use the achievements of acmeology in the sphere of professional activity. The paper presents acmeological analysis of such popular and widespread profession as a programmer. It should be noted that acmeology of programming has not been studied well enough despite a great number of publications and studies in acmeology of professional activity. The paper considers professional career of a programmer, the achievements of eight outstanding programmers having been analyzed in detail, and the results of the comparative empirical study to evaluate the potential of the programmers in a gender aspect being presented.

Keywords

Acmeological approach, Outstanding programmers, Gender differences, Recruitment process
\end{abstract}

\section{Introduction}

The success of innovative projects largely depends on the correct recruitment process. The famous phrase "Cadres decide everything (human resources are the principal driving force)" has always been universal. Perhaps for this reason the authors' attention was attracted by the article with the same title "Cadres decide everything" [1]. The author says: "From the point of view of psychology, the most socially active and productive period of human life is maturity, the age of $40-50 \ldots$ Many executives are looking for job candidates no older than 25 -years-old... It's time to turn to the completely unclaimed segment of the labor market".

The author of the article poses problems of vital importance. One can agree with the author in some cases, but some cases are disputable.

Such phenomenon as ageism is observed in many states. Indeed, recent decades have seen active attempts to "rejuvenate" staff. This tendency is observed both when companies and enterprises recruit permanent staff, and when they hire temporary staff for innovative projects.

Many authors address this issue, for example Solovjeva NV and Maksudova EA write: "In the labor market there are a lot of people with high work motivation and developed professionalism. They have only one weakness - their age: they are, as a rule, about 50-years-old and more" [2].
There is active support for young people, both during study at universities, post-graduate studies and in first years of work. A lot of money is allocated for the research work of young people: youth projects, grants, etc.

Is it always justified? Is age of 40-50 the most active and productive, as claims the author of the paper? These questions cannot be answered unambiguously, it is necessary to specify type of professional activity and turn to acmeology.

\section{Acmeology}

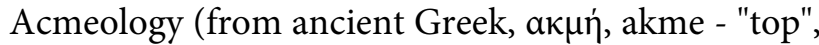
ancient Greek $\lambda o ́ \gamma o c$, logos - "doctrine") - the science of the laws (ways) of achieving perfection in all types of individual human activity. Modern acmeology is primarily interested in the age at which people of different professions reach the prime of life and how long they enjoy it [3].

*Corresponding author: NA Pakshina, Arzamas Polytechnic Institute of RE Alekseev, Nizhny Novgorod State Technical University, 19, Kalinina Str, Arzamas, 607220, Russia, Tel: +7987-3-33-810, E-mail: Nataliapakshina@mail.ru

Received: April 24, 2017; Accepted: July 13, 2017; Published online: July 15, 2017

Citation: Pakshina NA, Pravdina MV (2017) Acmeological Research Based on Personal History. Insights Anthropol $1(1): 11-15$

Copyright: (C) 2017 Pakshina NA, et al. This is an open-access article distributed under the terms of the Creative Commons Attribution License, which permits unrestricted use, distribution, and reproduction in any medium, provided the original author and source are credited. 
Acmeology is a science that emerged at the intersection of natural, social and human disciplines and studies the patterns and phenomena of human development to the stage of its maturity and, especially, when it reaches the highest level in this development [4].

Despite the fact that acmeology is a relatively young science, several directions have been formed in it, and one of the most practically demanded is professional acmeology, i.e. acmeology of specific professions or spheres of activity. And the age when prime of life is achieved in different areas is not the same.

The brightest manifestations of a person's talent at a young age are most often observed in the field of music and poetry. Vivid examples are Wolfgang Amadeus Mozart, who wrote his first works at the age of five, Mikhail Yurievich Lermontov, who at the age of fourteen wrote the poem "The Sail".

Historical experience shows that unlike the sphere of culture, in the field of science and technology the age limits when young talents are revealed are higher [5]. Their main achievements fall to a later age. But even in this sphere we can observe many examples when great discoveries are made and great achievements are obtained by very young people, for example mathematician Evariste Galois. Scientists who received their most outstanding results at a young age make up a considerable part of the total number of scientists [6].

As noted earlier, professional acmeology deals with specific professions or spheres of activity. And the age when prime of life is achieved in different areas is not the same.

This paper considers acmeology of such a demanded nowadays profession as a programmer. We will find out at what age programmers and information technology specialists reach their "tops".

Having considered a sufficiently large number of biographies of programmers and IT specialists, we decided to examine in details the activities of four outstanding male programmers and four bright female programmers.

Why outstanding? Would not it be more correct to study life, career, and achievements of ordinary representatives of this profession? The words of famous experts in acneology Dergach AA and Zazykin VG can be the answer to it: "Commonplace people do not create history and they are not written about" [7].

Professional acmeology has been studied by a great number of scientists. Let us name such researchers as $G$ Craig, D Baucum, R Droege, WV Schaufeli, C Maslach, T Marek, etc. [8-10]. MW Rossiter wrote a lot about women in science and in programming in particular $[11,12]$.
First we will conduct a small acmeological study taking as the example the activities of Mark Andresen, Dan Briclin, Linus Torvalds and Sergei Brin, while focusing on the age of obtaining major achievements.

\section{Analysis of the Activities and Achievements of Male Programmers}

Mark Andreessen (born 1971) is one of the young programmers of the world, famous for his outstanding computer developments, and most importantly for creating them at a very young age. At 21, Mark Andreessen together with young programmer Eric Bean after 3 months of hard work created the first Internet browser displaying graphics, which was later called Mosaic. At the age of 22, Mark Andreessen co-founded the famous company Netscape Communication [13]. Later, he founded his own firm Loud cloud. One of his very significant features, noted by all his colleagues, is the ability to learn and gain experience very quickly started his business as a student, and at 28 he was already 'the patriarch' of the Internet. It is no accident that Mark Andreessen is in the list of "people who changed the Internet" [14]. In this list you can see such outstanding people as Tim Berner-Lee, creator of the World Wide Web, Ray Tomlinson, Father of Emai, etc. All these people are the creators of innovative products that really changed our world.

Linus Torvalds (born in 1969) is the creator of the Linux operating system and the new business model. In 1992 (at the age of 23), Linus Benedict Torvalds, then a student at Helsinki University, presented a new Unixlike operating system Linux for IBM 386 to free access to everyone. Based on Minix, Linux 1.0 was released in 1994 (when he was 25 years), and in 1996 its creator just finished the university in Helsinki. At the heart of his project was "an extremely simple idea" (the so-called "open source principle") [15]. Linux is today the most vivid example of implementing ideas of "open" and "free". About 40,000 people took part in its creation absolutely free of charge. Linux was created by a new business model that involves free distribution of the source code of the main software and the sale of additional products and services created on its basis [16]. Linus Torvalds is known not only to specialists: in 2004 "Time" included him in the list of the most influential people in the world.

Dan Bricklin (born in 1951) is known as the "father of spreadsheets". He along with his fellow Bob Frankston created the first spreadsheet VisiCalc [17]. It appeared on the market on October 17, 1979 and cost only \$ 99. At this time, Dan was 28 -years-old. VisiCalc brought about a real revolution among entrepreneurs, managers and accountants. Bricklin's invention became the most popular program for financial tasks. Personal computers Apple II with VisiCalc installed were in great demand in the 
computer market. In 1981, Daniel Bricklin was awarded the Grace Murray Hopper Award for significant achievements in the field of computers as an inventor younger than 30-years-old [18].

Sergei Brin (born 1973) in 1996 (at the age of 23), when working on his $\mathrm{PhD}$ thesis, together with a young scientist Larry Page started a project aimed at improving the methods of searching information on the Internet [19]. Initially, the search engine was posted on the Stanford University website under the domain google. stanford.edu. The domain google.com was registered on September 14, 1997 (Sergei was only 24-years-old). A little later the well-known company Google was created, whose products are now used by a lot of people.

It is evident that the contribution of young programmers is not only great, but also very diverse. The analysis made it possible to draw the following conclusions: all of them were united by one common feature: they all brought something completely new into the world, something that had no prototypes; all of them received their main results at the age of 20 to 28 -years-old [20].

If we return to the question posed at the beginning of the paper, what age is the most productive, then it turns out that employers might be right when giving preference to 25 -year-olds. However, our analysis will be one-sided, and the conclusions premature, if we do not consider the activities of some female programmers who also have significant merits.

\section{Analysis of the Activities and Achievements of Female Programmers}

Unfortunately, it is widely believed that women and technology are incompatible things. At the same time, many universities have about $50 \%$ of female students at the departments of Information Systems and Technology and Applied Mathematics. It is possible that when employed they will have to face some gender discrimination first, and later ageism. Let's continue our acmeological analysis and consider the life and creative activity of four outstanding programmers Ada Augusta Lovelace, Grace Murray Hopper, Catherine Logvinovna Yushchenko and our contemporary Frances Elizabeth Allen.

Ada Lovelace in 1843 translated the Luigi Menabria's paper, written on the basis of the Charles Babbage's lectures about his analytical machine, and added comments where she formulated the main principles of programming for this machine, and also developed the first program for it (at the age of 28) [16]. She introduced the terms "working cell" and "cycle". In the first half of XIX she suggested that the computer would compose musical works, draw pictures and be used in practical and scientific work. Time has confirmed accuracy of her fore- casts. Ada Lovelace laid the theoretical foundations of programming and is rightfully considered the world's first programmer. The programming language "Ada" is named in her honor.

Grace Hopper in 1944 wrote the first subprogram for calculating $\sin (\mathrm{x})$ on a Mark I computer (at the age of 38-years-old), later took part in the development of assemblers, and in 1961 was one of the main consultants in the creation of the COBOL language (at age 55). The colleagues jokingly called her "Grandmother of COBOL". And in 1969 it was Grace Murray Hopper who was awarded the title of the "person of the year" in the computer world of the USA (63 years). She is the only woman in the rank of Rear Admiral of the US Navy [21]. From 1982 until her final retirement in 1986, she was the oldest active officer in the American army. And she was 80 -years-old! In the spring of 1996, the guided missile destroyer named in her honor USS Hopper was commissioned by the Navy in San Francisco.

Ekaterina Yushchenko worked in the field of computational mathematics since 1954 (35-years-old), developed algorithms for MESM, including algorithms for solving external ballistics problems for rocket and space complexes. She created (at 36) Address language, one of the first programming languages, which predetermined the appearance of many modern languages. Address language was included in a number of programming languages. Ekaterina Logvinovna Yushchenko (at the age of 47) became the first Doctor of Physical and Mathematical Sciences in programming in the USSR (The Russian Doctor of Science degree is the highest research degree in this country) [16]. Over the period of her highly impressive academic career, Yushchenko supervised 45 Ph.D students and 11 Doctors of Science.

Francis Elizabeth Allen is an American scientist in the field of computer theory. She worked at IBM for 45 years (from the age of 25 to 70 -years-old). Her achievements include seminal work in compilers, code optimization, and parallelization. She also had a role in intelligence work on programming languages and security codes for the National Security Agency [22]. Having left IBM in 2002, she continued to consult IBM on a number of projects, including the Blue Gene supercomputer, and worked to help attract other women to computer-related fields of science. FE Allen is the first woman to be awarded the Turing Award (74-years-old).

\section{Conclusions}

Analysis of the creative activity of these people allows us to a certain extent to dispel the myth based on the biography of Bill Gates that the talent rise of young people is due to the interruption of studies and early practical activities. The programmers we examined were under- 
Citation: Pakshina NA, Pravdina MV (2017) Acmeological Research Based on Personal History. Insights Anthropol 1(1):11-15

Table 1: Questionnaire.

\begin{tabular}{|l|l|l|l|l|}
\hline Full name & Scientific degree position & $\begin{array}{l}\text { Age when most significant } \\
\text { results were obtained }\end{array}$ & Current age Age of children & Gender \\
\hline & & & \\
\hline
\end{tabular}

graduates or graduate students, i.e. had at least a bachelor's degree at the time they received the main results.

Age analysis of the activity of female programmers showed that their main achievements were obtained in the interval from 28-38 years and older, while the peak of cognitive and creative abilities among the male programmers considered falls at the age of 20 to 28-years-old.

We anticipate the opponents' objections. The selected female programmers lived in an earlier time period than the selected male programmers. In this case, it is really difficult to take into account the characteristics of socialization in different generations.

The study of achievements and biographies of only eight programmers does not give us the right to speak about reliable statistical data and draw definitive conclusions. However, qualitative regularities can be noted. At this stage the authors committed themselves to a fairly modest goal of conducting qualitative analysis and determining the ways of further research.

Indeed, the burst of creative activity among male programmers usually comes from about 20 to 30 , in the case of women this period is shifted by 10-20 years. This discrepancy is due to both the physiological characteristics (childbearing period) and the need to grow children, and only then to fully engage in the work.

Ada Lovelace, for example, wrote the first program in 1843 at the age of 28 , when she had two sons (7-yearold and 4-year-old) and a 5-year-old daughter. Yekaterina Yushchenko gave birth to her son when she was 31-years-old, and created her Address Language five years later.

The maximum potential depends on the time that a scientist can devote to research. In case of women, this potential will be less than that of male colleagues who are not burdened with daily household duties and childcare. In our examples, only Countess Ada Lovelace was not burdened with household activities.

The following facts confirm that problem of women's discrimination in this profession has always existed. When publishing reviews, Ada Lovelace used only the initials A.A.L. but not the full name. Nearly 200 years later in 2002, Joanna Rutkowska, a Polish specialist in computer systems security, published her first scientific articles under the man's name Jan Krzysztof Rutkowski [23].

The authors plan to continue studying various aspects of this problem.

\section{Future Plans}

- Increase the number of female and male programmers to analyze and compare.

- Develop a table structure with criteria and formalized indicators of achieving acme by programmers.

When analyzing biographies, the age of obtaining the most significant results is often judged on the basis of indirect evidence, such as recognition, awards, financing of projects. Recognitions and awards often happen to be much later than the achievements themselves. For example, Linus Torvalds received the 2014 IEEE Computer Society Computer Pioneer Award twenty years after the release of the first versions of Linux. The early pioneer of computer science Alexey A Lyaponov was awarded the Computer Pioneer Award in 1996, i.e, 23 years after his death.

The experts themselves can estimate their achievements more precisely. We decided to conduct a survey on the International Federation of Automatic Control (IFAC) World Congress. This scientific event will bring together many specialists engaged not only in automatic control, but also in programming, algorithmization and other computer sciences. It will be held in France in Toulouse in July 2017.

We are planning to conduct the survey during this congress, and ask the respondents to fill in the form presented in the Table 1.

At the same time, the main indicator will be the real age of obtaining the most significant results, and not the fact of recognizing these results.

We would like the heads of personnel departments, innovative projects, and people who are directly involved in the recruitment of personnel to study and take into account the achievements of acmeology taking into account the gender factor, and then their activities will be more effective.

\section{References}

1. http://www.mosresult.ru/Data/Articles-new/Cadres_solve_ everything.html

2. Solovjeva NV, Maksudova EA (2012) Interaction of staff with professional environment. J Acmeology 1: 29.

3. http://www.psychologos.ru

4. Derkach AA (2004) Acmeological basis of professional development. Moscow Psychological and Social Institute and NGO "MODEC", RU. 
Citation: Pakshina NA, Pravdina MV (2017) Acmeological Research Based on Personal History. Insights Anthropol 1(1):11-15

5. Pakshina AP (2008) The research of young genius's phenomenon. Proceedings of the $14^{\text {th }}$ Int. Oficyna Wydawnicza Polytechniki Wroclawskiej, Wroclaw Poland.

6. Pozdyaev VI, Pakshina AP (2006) On the phenomenon of young talents. J Fundamental Research 12: 51-53.

7. Dergach A, Zazykin V (2003) Akmeology: Textbook. Peter, RU 13.

8. Craig GJ, Baucum D (1976) Human development. ( $9^{\text {th }}$ edn), Prentice Hall.

9. Droege R (1982) A psychosocial study of the formation of the middle adult life structure in women. Unpublished doctoral dissertation. California School of Professional Psychology, Berkeley.

10. Schaufeli WB, Maslach C, Marek T (1993) Professional burnout: Recent developments in theory and research. Taylor \& Francis, Washington DC.

11. Rossiter MW (1982) Women Scientists in America: Before Affirmative Action, 1940-1972. Johns Hopkins University Press, Baltimore.

12. Rossiter MW (2012) Women Scientists in America: Forging a New World since 1972. Johns Hopkins University Press, Baltimore.
13. 40 People Who Changed the Internet.

14. Woodcock J (1999) Step Up to Networking (IT Professional). Paperback-Microsoft Press, USA, 247-248.

15. Torvalds L, Diamond D (2001) Just for Fun, The Story of an Accidental Revolutionary. Harper Business, USA.

16. Pakshina NA (2007) History of Computer Science and Computing Mechanisms. NNSTU, Russia.

17. VisiCalc: Information from its creators, Dan Bricklin and Bob Frankston.

18. http://www.bricklin.com

19. 5 refugees who changed the world.

20. Pakshina NA (2013) Acmeology of programming in gender aspect. J Akmeologiya 4: 91-95.

21. Chastikov AP (1995) History of Informatics in Persons: Grace Hopper. J Informatics and Education 3: 23-27.

22. AM Turing award winners.

23. Rutkowski JK (2002) Execution path analysis: finding kernel based rootkits. J Phrack 11. 